International Journal of Applied Linguistics \& English Literature

ISSN 2200-3592 (Print), ISSN 2200-3452 (Online)

Vol. 1 No. 6; November 2012

\title{
(EGL) and Contrastive Rhetoric: Reflections from L2 Writing Research
}

\author{
Hosney M. El-daly \\ Department of Linguistics, College of Humanities and Social Sciences \\ United Arab Emirates University, P.O.Box: 17771, Al-Ain, U.A.E. \\ E-mail: hasan.mostafa@uaeu.ac.ae
}

Received: 19-07- 2012

doi:10.7575/ijalel.v.1n.6p.154
Accepted: 12-08- 2012

Published: 01-11- 2012

\begin{abstract}
This study argues that if we, really, accept English as a global language, and diversity of cultures, we have to better understand the different composing conventions of different cultures; otherwise, written communication among people of different cultures may break down. This argument is theoretically based on a number of premises drawn from Purves's (1988) extensive research in contrastive rhetoric. With this in mind, the present study attempts to show how Arabic and Spanish speakers narrate in English and, to what extent their native cultures affect their narrative written productions. In addition, some of the cognitive factors that may shape the subjects' written productions were discussed. Using Laböv' sociolinguistic model of narrative structure, this study shows that the narrative texts of both Arabic and Spanish speakers share almost all the structural properties of Laböv's model. This finding may lead us to claim that regardless of the subjects' linguistic and cultural backgrounds, the narrative structural components seem to be somehow universal. This claim needs to be tested with low-level subjects of various languages and cultures.
\end{abstract}

Key words: (EGL), Contrastive Rhetoric, Narrative Writing, Cognitive and Cultural factors.

\section{Overview}

\subsection{The Purpose}

This study was conducted to investigate and interpret differences between native speakers of two language backgrounds-Arabic and Spanish -writing in English. "Information about such differences may contribute to contrastive rhetoric research, which maintains that written first language texts by authors from different language groups vary because cultural conventions dictate the choice of linguistic and structural aspects of discourse" (Purves, 1988:5). Therefore, this case-study aims at analyzing the narrative texts of native speakers of two language backgrounds: Arabic and Spanish, with a view to answering the following question: how do Arabic and Spanish speakers narrate and what are the major rhetorical properties of their narrative written texts?

\subsection{Participants}

The subjects of the study were ten foreign students who belonged to two different linguistic and cultural backgrounds. The first was from the Arabic language group and the second was from the Spanish linguistic group. The ten subjects were engaged in advanced graduate studies in various majors at the University of Pittsburgh, U.S. A.

All Arabic subjects were males. They were between thirty- three and forty-four years old. Four of them were studying for their Ph. D. in various areas of study: Linguistics, physical education and foreign language education. The fifth subject was studying for his Masters in public administration. Two of the five Arab subjects had been in the U.S.A for five years, one for four years, one for three years, and one for two years. Four subjects had never been in an English- Speaking environment before coming to the U.S.A. Only One subject had been in England for two years. Two of the five Arab subjects had studied English in their home countries for ten years, one for twelve years; one for six years, and One for four years.

Four Spanish subjects were females and one was male. They were between the ages of twenty-seven and thirty-nine. Four were studying for their Ph. D. in various areas of study: applied linguistics, Hispanic 
International Journal of Applied Linguistics \& English Literature

ISSN 2200-3592 (Print), ISSN 2200-3452 (Online)

Vol. 1 No. 6; November 2012

sociolinguistics, computer science, and economic development. The fifth subject was studying for her Masters in Latin American history.

Spanish subjects had been in the U.S.A for various periods of time; one subject for six years; one for five and a half years; one for two years; one for one year; and one for less than a year. None of them had ever been in an English-speaking environment. One of the five subjects had studied English in her home country for twenty - five years; Three for two years, and One for one year.

\subsection{Hypotheses}

The present study is based on the following premises, drawn from Purves' (1988) extensive research in contrastive rhetoric:

1. Writing is a social phenomenon. It is an act for negotiating meaning with some identifiable set of human beings and this requires far more than a minimal control of syntactic and lexical items in the target language;

2. Morphosyntactic competence is only a prerequisite to writing in a foreign / second language: That is, the fact that a student can understand the structure of individual sentences in a language does not necessarily guarantee that he / she can produce coherent and communicative written texts in that language (See Segalowitz, 2011; Spada, 2006; Stigler \& Hiebert, 2009; Tyler, 2011; Van Weijen et. al, 2008; Weijen et al., 2009; Wong, 2005, Wong. L. 2001).

3. Different composing conventions do exist in different cultures. Every culture has its own specific conventions that may distinguish it from other cultures, and

4. If we, really, accept "English as a Global Language (EGL) and diversity of cultures, we have to better understand the different composing conventions of different cultures; otherwise, "written" communication among people of different cultures will break down(See Chandler, 2011; Cobley, 2011; Loewen et al., 2009: Mangubhai, 2006; Schoonen et al., 2003).

\subsection{Procedures}

The subjects in each language group were asked to write a narrative essay. The members of each language group were supposed to meet in one group session to receive instructions, and then to do the writing task. However, since it was impossible to get the members of each group to approve of a specific meeting time, I had to meet with each subject at his/her convenience.

In the first meeting each subject in each language group was asked to write a narrative text on the topic stated in (Appendix 1). Instructions were given to each subject before $\mathrm{s} /$ he wrote. I gave these instructions orally at the beginning of this meeting. At the end of this session, each subject was reminded of the next meeting. Once again, every subject had the chance to choose the time and place of the meeting. That is, the exact day and time of the meeting was specified after consultation with each subject.

After the subjects in both language groups wrote their texts, they were interviewed individually. Each subject was asked to describe how/he approached the narrative texts; how s/he started the essay, developed his/her thoughts and ended his/ her essay. These interviews were conducted in English for both groups. The subjects' explanations were transcribed by the researcher. The mechanism of conducting the interviews is based on Gass' (1983) claim that one of the ways to understand the mechanisms of $\mathrm{L}_{2}$ learners' performance is to ask them (Learners). Specifically, Gass suggests that for second language learners the ability to think and talk about language might involve abstract analyses of a number of different types. It might include, for example, (1) analyses of their own language, (2) a comparison between their native language and the target language, (3) a comparison between their native language and other languages previously learned, or even (4) a comparison between the target language and other languages previously learned (p.277).

The subjects' written narrative texts were analyzed using Laböv's sociolinguistic model of narrative structure. This model was developed by the American sociolinguist William Laböv and his associates (Laböv, 1972) working on Black English Vernacular (BEV) in New York. Initially, narratives were examined in the context of a study set up to investigate the notion of linguistic "deprivation" in Black communities and its educational implications. It was discovered not only that the collected narratives regularly exhibited evidence of considerable facility on the part of the narrators in the use of English, but also that the narratives most highly prized had structural properties in common. In this regard, Carter $(1998: 180)$ points out that: "The structural features extrapolated by Laböv were not highlighted by intuition but were observed to correlate with particular linguistic forms and stylistic patterns. Such observations make it easier to work with Laböv's model. Unlike some narrative models where it is difficult to retrieve the analyst's decision to assign a part of the narrative to one category rather 
than to another, Laböv's model is generally most attestable".

According to Laböv, a fully formed or proficient narrative of personal experience (that is, a story you tell about something that happened to you - as contrasted with a narrative of vicarious experience) would have most if not all structural properties (See Appendix 2). Finally, Carter (1997: 182) rightly maintains that "it is a key principle of working with models in such contexts that they should not be seen as finite or self- complete but rather as hypotheses to be tested against data".

\section{Theoretical Framework}

David Crystal, world authority on the English language, has written an informative account of the phenomenon of English as a global language. His views, as expressed in his book "English as a global Language", constitute the theoretical framework; justification, and motivation for doing this piece of research. In the following section, Crystal's major ideas, which are quite pertinent to the present study, will be presented.

First, Crystal points out that there is no more intimate or more sensitive an index of identity than language, the subject is easily politicized. That is, people have a natural wish to use their own mother tongue, to see it survive and grow, and they do not take kindly when the language of another culture is imposed on them. Accordingly, the people of some countries may feel so antagonistic or ambivalent about English that they reject the option to give English a privileged status, either as an official language or as a foreign language. The president of Kenya, Jomo kenyatta, said in 1974: "The basis of any independent government is a national language; and we can no longer continue aping our former colonizers". Gandi, writing in 1908, puts the point more emotively: "To give millions knowledge of English is to enslave them... Is it not a painful thing that, if I want to go to a court of Justice, I must employ the English Language as a medium; that, when I became a Barrister, I may not speak my mother-tongue, and that someone else should have to translate to me from my own language? Is this not absolutely absurd? Is it not a sign of slavery?" (cited in Crystal, 1998).

In his book, "Decolonising the Mind", the Kenyan author, Ngugi (1986) rejected English as the medium of expression: "In the $18^{\text {th }}$ and $19^{\text {th }}$ centuries Europe stole art treasures from Africa to decorate their houses and museums; in the $20^{\text {th }}$ century Europe is stealing the treasures of the mind to enrich their languages and cultures. Africa needs back its economy, its politics, its languages and all its patriotic writers" (cited in Crystal, 1998). The above arguments are all to do with identity, and with language as the most immediate and universal symbol of that identity.

Second, the need for intelligibility and the need for identity often pull people - and countries -in opposing directions. The former motivates the learning of an international language, with English the first choice in most cases; the latter motivates the promotion of ethnic language and culture. In fact, the existence of vigorous movements in support of linguistic minorities, commonly associated with nationalism, illustrates an important truth about the nature of language in general: "Language is a major means (some would say the chief means) of showing where we belong, and of distinguishing one social group from another, and all over the world we can see evidence of linguistic divergence rather than convergence" (Crystal, 1998:19).

In this connection, Crystal, further, maintains that arguments about the need for national or cultural identity are often seen as being opposed to those about the need for mutual intelligibility. But this is misleading. It is perfectly possible to develop a situation in which intelligibility and identity happily co-exist. This situation is the familiar one of bilingualism, but a bilingualism where one of the languages within a speaker is the global language, providing access to the world community, and the other is a regional language, providing access to a local community. The two functions can be seen as complementary, responding to different needs. And it is because the functions are so different that a world of linguistic diversity can in principle continue to exist in a world united by a common language. Personally, I do agree with Crystal when he makes the following claims: (1) "I believe in the fundamental value of multilingualism as an amazing world resource which presents us with different perspectives and insights, and thus enables us to reach a more profound understanding of the nature of the human mind and spirit. In my ideal world, everyone would be at least bilingual. (2) "I believe in the fundamental value of a common language, as an amazing world resource which presents us with unprecedented possibilities for mutual understanding, and thus .enables us to find fresh opportunities for international co-operation. In my ideal world, everyone would have fluent command of a single world language". Crystal justified his beliefs as follows: "We need to take both principles if we are to make any progress towards the kinds of peaceful and tolerant society which most people dream about. The first principle fosters historical identity and promotes a climate of mutual respect. The second principle fosters cultural opportunity and promotes a climate of international intelligibility" (p. xi). 
Third, a language does not become a global language only because of its intrinsic structural properties, or because of the size of its vocabulary, or because it has been a vehicle of a great literature in the past, or because it was once associated with a great culture or religion. Crystal maintains that these are all factors which can motivate someone to learn a language, but none of them alone, or in combination can ensure a language's world spread. The question which imposes itself, in this regard, is "why has a language become global?"

According to Crystal, a language achieves a genuinely global status when it develops a special role that is recognized in every country. To achieve such a status, a language has to be taken up by all countries around the world. They must decide to give it a special place within their communities. And, there are two main ways in which this can be done: (1) a language can be made the official language of a country, to be used as a medium of communication; (2) a language can be made a priority in a country's foreign - language teaching, even though this language has no official status. It becomes the language which children are most likely to be taught when they arrive in school, and the one most available to adults who for whatever reason never learned it, or learned it badly, in their early educational years.

Four, why a language becomes a global language has little to do with the number of people who speak it . It is much more to do with who those speakers are. Simply speaking, there is a close link between language dominance and the cultural and political power of its people, especially their military power. In this connection, Crystal maintains that "without a strong power-base, whether political, military or economic, no language can make progress as an international medium of communication. Language has no independent existence living in some sort of mystical space apart from the people who speak it. Language exists only in the brains and mouths and ears and hands and eyes of its users. When they succeed, on the international stage, their language succeeds. When they fail their language fails" (p.5).

Five, language becomes an international language for one chief reason: The political power of its people especially their military power. The explanation is the same throughout history: (1) why did Greek become a language of international communication in the Middle East over 2,000 years ago? ; (2) why did Latin become known throughout Europe ?; (3) why did Arabic come to be spoken so 'widely across northern Africa and the Middle East?; (4) Why did Spanish, Portuguese, and French find their way into the Americans, Africa, and the Far East? The answer is one in all cases, and lies mainly in the political, military and religious power of the people of those languages. However, Crystal argues that international language dominance is not solely the result of military might. It may take a military powerful nation to establish a language, but it takes an economically powerful one to maintain and expand it. This has always been the case, but, it becomes particularly critical factor early in the $20^{\text {th }}$ century:

1. Economic developments beginning to operate on a global scale, supported by the new communication technologies;

2. The growth of competitive industry and business brought an explosion of international marketing and advertising.

3. The power of the press reached unprecedented levels, soon to be surpassed by the broadcasting media, with their ability to cross national boundaries with electromagnetic ease.

4. Technology, in the form of movies and records, fuelled, new mass entertainment industries which had a worldwide impact.

5. The drive to make progress in science and technology fostered an international intellectual and research environment which gave scholarship and further education a high profile.

Any language at the centre of such an explosion of international activity would suddenly have found itself with a global status.

Six, English was in the right place at the right time. By the beginning of the $19^{\text {th }}$ century, Britain had become the world's leading industrial and trading country. By the end of the century, the population of the USA (then approaching 100 million) was larger than that of any of the countries of western Europe, and its economy was the most productive and the fastest growing in the world "British political imperialism had sent English around the globe, during the $19^{\text {th }}$ century, so that it was a language "on which the sun never sets". During the $20^{\text {th }}$ century, this world presence was maintained and promoted, almost single-handedly, through the economic supremacy of the new American superpower. And the language behind the US dollar was English. Therefore, "Governments who wish to play their part in influencing the world's linguistic future should therefore ponder carefully, as they make political decisions and allocate resources for language planning. Now, more than at any time in linguistic history, they need to adopt long-term views, and to plan ahead-whether their interests are to promote English or to develop the use of other languages in their community (or, of course, both). If they miss this linguistic boat, there may be 
International Journal of Applied Linguistics \& English Literature

ISSN 2200-3592 (Print), ISSN 2200-3452 (Online)

Vol. 1 No. 6; November 2012

no other" (Crystal, 1998:23).

The last point that needs to be emphasized is that accepting English as a global language does not mean ignoring linguistic diversity. Rather; linguistic diversity is a must keeping in mind the nature, significance and role of language. It will continue in a world united by a common language. (Walker, 2011; Van Patten \& Williams, 2008).

\section{Rationale}

In his provocative book "the Tongue-Tied American", Paul Simon (1980) recounts the story of a Georgia school board member who approached Genelle Marian of the University of Georgia with the question: "why should a student who will never leave Macon, Georgia, study a foreign language?. Her replay to that challenge was succinct but profound: "That is why he should study another language". Such a reply reflects the value of second language competence and cross-cultural understanding in a global economy. For Chomsky, the reply would be language is a mirror of the mind; that is, by detailed study of language, we might hope to reach a better understanding of how the human mind produces and processes language (Radford, 1981:1). Chomsky (1972:103) himself remarks: "There are a number of questions that might lead one to undertake a study of language. Personally, 1 am primarily intrigued by the possibility of learning something, from the study of language, that will bring to light inherent properties of the human mind".

In fact, it was the German philosopher Wilhelm Von Humboldt who drew our attention to the relation between language and thought. He drew strong ties between the language of a people and their spirit or culture and, also, emphasized that language has an "inner form" corresponding to the psychological structure of the individual. Von Humboldt's early views have been further developed by American linguists such as Boas, Sapir and Whorf. Boas (1986/1911), for example, claimed that linguistic formulations reflect the forms of thought identifiable in a culture. Consequently, linguistic forms can be used to investigate the differences in the history of "mental development" of various cultures. Edward Sapir (1949/1921), also, points out that "language and our thought grooves are inextricably interrelated"(p.219). And, language "actually defines experience for us by reason of its formal completeness and because of our unconscious projection of its implicit expectations into the field of experience... linguistic form has "a tyrannical hold... upon our orientation in the world" (1969/1931:128). Similarly, Whorf (1956) maintains that "the background linguistic system of each language... is itself the shaper of ideas, the program and guide for the individual's mental activity, for his analysis of impressions, for his synthesis of his mental stock in trade. Formulations of ideas is not an independent process.. but is part of a particular grammar, and differs from slightly to greatly, between different grammars" (p.212-3). This idea is also expressed by Onaka (1984: 15) as follows:

"There are many cultures in the world. Just as people differ in appearance, so the language and thought patterns vary from culture to culture, and the psychological structure influences the shape of the rhetorical framework. This framework is an important part of a language, but it has long been ignored by many teachers, who tend to emphasize only phonological, syntactic, and semantic differences, because they are obvious and easily taught".

The extents to which language, culture, and thought have influenced one another, and which is the dominant aspect of communication, have been matters of controversy for three quarters of a century. The current consensus is that the three aspects are three parts of a whole, and cannot operate independently; regardless of which one influences the other two. To see them as three points in a constantly flowing circular continuum is surely more accurate than, say, to see them as an isosceles triangle, with one dominant over the other two (Valdes, 1989:1). In this connection, Marshall (1979: 6) maintains that "the most basic of psychological processes are shaped by cultural influences... Our perceptual functioning seemingly involves selective filters derived from culturally shaped experiences".

Simply, each person, wherever he dwells, is an individual, but an individual influenced by family, community, country, and even language. In this connection, Valdes (1989) points out that "when a person who has been nurtured by one culture is placed in juxtaposition with another, his reaction may be anger, frustration, fright, curiosity, entrancement, repulsion, confusion. If the encounter is occasioned by study of another language, the reaction may be stronger because he is faced with two unknown simultaneously. Such a predicament may be very threatening, and until the threat is removed, language learning may be blocked" (p.vii).

Once-the second language learner comes to understand the behavior of the speakers of the target language, regardless of the original motivation for study, the task of adding the language becomes far simplier, both through acceptance of the speakers of the language and through increased knowledge of what the language means, as well as what it says. The research of Gardner and Lambert (1972) determined that integrative motivation (the intention 
of becoming a part of the target culture as well as speaking the target language) resulted in more effective language learning than did instrumental motivation (the intention of learning the language to serve a purpose, such as getting a job, with no wish to mix socially with speakers of the language (See Brown, 2009; Casanave, 2004; Conley, 2008; El-daly, 2010; Eslamina \& Fatahi, 2008; Field, 2011).

\section{Language Teaching and Culture: Focus on the Written Text}

There is no question that the successful integration of culture and language teaching can contribute significantly to general humanistic knowledge, that language ability and cultural sensitivity can play a vital role in the security, defense, and economic well-being of the whole world and that "global understanding ought to be a mandatory component of basic education" (Galloway, 1985). In her article, a "Toward a cultural reading of authentic texts", Vicki Galloway (1992:33) stresses the importance of recognizing the pervasive influence of culture on one's attitudes, emotions, beliefs, and values: "Cultures are powerful human creations affording their members a shared identity, a cohesive framework for selecting, constructing, and interpreting perceptions, and for assigning value and meaning in consistent fashion... Things that fit into this cultural-framework are given the labels "human nature", instinct, "common sense", "logic". Things that don't fit are "different", and therefore either naive or inferior stage of development of human nature".

Specifically speaking, as Grabe and Kaplan (1989) argue, different languages have different rhetorical preferences in textual organization, preferences reflected in syntactic and other textual differences. This is why when Arabic speaking students seem to have mastered most of English grammatical forms and idioms; they still produce "foreign sounding essays". Experienced ESL writing teachers can identify Arabic-speaking students' English essays as having been written by Arabic-speakers, even when these essays are free from grammatical errors (Ostler, 1988:260). It may be pertinent, now, to shed, some light on what has been known as "Contrastive Rhetoric".

\subsection{Contrastive Rhetoric}

Research on contrastive rhetoric has two premises. First, rhetorical norms being shaped by the native language and culture are language/ culture specific. Second, the natively acquired rhetorical norms are transferred to the $F_{1}$ writing. As Kaplan (1966) argues, no matter how proficient the FL learners, their compositions will be rhetorically deviant from the accepted norms of the target language.

This type of research has had two main directions. First, researchers have been concerned with comparing rhetorical patterns across various native languages (Hinds, 1983; Regent, 1985; Kachru, 1989). Second, researchers have focused on comparing the compositions of the native speakers and the non-native speakers of the same language (Bickner and Peyasantiwong, 1988; Hansen-strain, 1992). These studies tended to interpret the differences between English $\mathrm{L}_{1}$ and $\mathrm{L}_{2}$ compositions in terms of the influence of the writer's native cultural norms. Other studies report that no indication of native language/ culture transfer can be identified in the EFL compositions they examined (Connor and Mc Cagg, 1983; Connor, 1987).

Kaplan (1966) conducts the first contrastive rhetoric study. He argues that the writing of individuals reflects the rhetorical patterns esteemed in their native cultures, and that, when individuals write in other than their native languages, they tend to use their native patterns in that discourse. And, in spite of mastering syntactic structures foreign students are incompetent writers of academic English. This incompetency is due to the tendency on the part of these students to apply their native language/ culture through patterns in paragraph development, which are basically different from those applied in English.( See Beare \& Bourdages, 2007; Bitchner \& Bastukman, 2006; Ferris, Hedgcock, 2005; Gregorius, 2011; Hirose, 2003; Hua, 2011). More particularly, Kaplan contends that logic, as a cultural phenomenon, is "not universal". And, since logic is the "basis of rhetoric", then rhetoric also "varies from culture to culture and even from time to time within a given culture"(p.2). Consequently, the thought patterns and the related rhetorical conventions vary among natives of different cultures / languages. These differences are manifested, according to Kaplan, in texts written in foreign languages, where the writers follow the discourse conventions of their native languages.

Moreover, Soter (1988) indicates that ESL writers bring various cultural and educational experiences with them to their second language writing experiences: "they have been enculturated with regard to language in a variety of contexts and genres" (p.201). In Ostler's (1988) study on Arabic -, Spanish-, and Chinese Speakers writing in English, both Arabic and Spanish writers (but not Chinese writers) used significantly more co-ordinate conjunctions, and significantly fewer prepositions and passive-voice verbs. Ostler indicated that one reason for the similar linguistic co-occurrences in Arabic and Spanish may be the influence of 600 years of occupation by the 
Moors in Spain. She, finally, concluded that "Various cultures organize the development of ideas differently ... and these differences persist when speakers of these cultures learn to write in a new language" (p.260)

On the other hand, Vahapassi (1988) proposes that different cultures differ in term of the functions of writing emphasized in school, typical writing assignments, and appropriate topics to write about and appropriate form of task instruction. That is, the approach to writing instruction adopted in different cultures and school systems is related to the general goals of education, the conception of language functions, and the process of writing. This view is also held by Leki (1991) who proposes that since writing is mainly "school sponsored", it is influenced by the culture of the school system. The discourse styles learned at school are those preferred by that culture. The age and education level of the majority of EFL learners in English speaking countries support these hypotheses even further, as Leki proposes. Since most of these students are graduated, they are expected to have mastered the written discourse conventions of their native cultures. Their problems in EFL writing, then, are the result of negative transfer of these conventions. In this regard, Purves (1988: 221) also, remarks: "It has been recognized that writers from different cultures have learned rhetorical patterns that may differ from those used in the academic settings in the U.S.A. and that are reinforced by their educational experience in their cultures".

In addition, Hull (1989:109) maintains that "to say that writing is embedded in a context is to acknowledge that what counts as writing, or as any skill or any knowledge, is socially constructed. It depends for its meaning and its practice upon social institutions and conditions. According to this view, writing does not stand apart from people and communities. And this new understanding carries with it different notions of how writing is acquired and by whom". In his psycholinguistic study, Bloom (1981) examined the influence of language on abstract conceptual thinking. Bloom hypothesized that when a language provides a label for "any specific mode of categorizing experience... it encourages its speakers to develop a labeled cognitive schema specific to that mode of thought" (p.20). Similarly, Hoffman et al. (1986: 103) argue that "different languages, because they label certain perspectives on the world but not others, must affect their speakers' repertories of schemata in language-specific ways". (See Jiang, 2007; Kimberly, 2009; Knutson, 2006; Leeuwen, 2011).

Friedlander (1990) claims that if ESL writers retrieve information about a writing topic from memory in their first language and then have to translate into English before writing anything down, this act of translation can lead to an overload of their short-term memory and a diminishment in the quality of the content of their writing. His study on 28 Chinese-speaking subjects supported the hypothesis that ESL writers would be able to plan more effectively and write better texts when they planned in Chinese for the Chinese topic and in English for the English topic. Also, regardless of the language used, however, writers did a better job of planning and text production on the Chinese topic than on the English topic (See Lee, 2005; Mc Carthey et al., 2005; Mu \& Carrington, 2007; Ong \& Zhang, 2010; Manchon et al., 2009; Kellogg, 1996; Leki et al., 2008).

Moreover, a number of studies have indicated that, regardless of a language prescription, writers will transfer writing abilities and strategies, whether good or deficient, from their first language to their second language. For example, Jones and Tetroe (1987) found that ESL writers transferred both good and weak writing skills from their first language to English. This transfer was independent of language proficiency, which affected only quantity of planning. They suggested that strategies that were never acquired in $\mathrm{L}_{\mathrm{I}}$ could not be transferred to $\mathrm{L}_{2}$ (See Nation, 2009; Kuiken \& Vedder, 2008; McCutchen, 1996).

Evidence of a first language assisting writers can be found in some studies of ESL adults. Lay (1982), for example, found that her Chinese subjects tended to switch to using their first language when writing about a topic studied or acquired in their first language background. She, also, reports that their first language served as an aid and not a hindrance to writing. Lay notes that the greater the number of switches into the first language, the better the quality of the essays in terms of organization and ideas. Cumming (1987), also, reports that inexpert French ESL writers use their first language to generate content, regardless of the language of the topic. In contrast, expert writers use translation not just to generate content but also to generate and verify appropriate word choice (See Nunan, 2011).

Reid (1990) maintains that second language writers who are successful writers in the their first languages often know what is socially and culturally appropriate in terms of the writer roles, audience expectations, rhetorical and stylistic conventions, and situational or contextual features of written text in their native languages. However, Kaplan (1988: 294) argues that there is "no reason to assume that the non-native English speaker will be aware of this set of conventions in English, or that the learner will be able to acquire these conventions for him-or herself" (See Shehadeh, 2011; Doalan \& Miller, 2012; Alwi et al., 2012; Darvishzadeh et al., 2012; Klimova, 2011; Petric, 2012). 
To sum up, both the content and the language to express this content are culturally determined. To be effective, writers have to learn what is expected of them within their own culture. Consequently, differences in cultural expectations arc an obstacle for those who are learning to write in a foreign language. Under the influence of the norms within their own culture, they may deviate from the norms of the foreign culture in what kind of material are to be included in a particular variety of written discourse, what style is appropriate, and how the discourse is to be organized. Purves (1988: 19) points out that "the differences among rhetorical patterns do not represent differences in cognitive ability, but differences in cognitie style. When students taught to write in one culture, enter another and do not write as do the members of the second culture, they should not be thought stupid or lacking in "higher mental processes".

Recalling Rumelhart's (1975) notion of Schema theory, it appears that in order for $\mathrm{L}_{2}$ learners to write effectively in a second language, they must develop the schemata related to the written rhetorical styles of the target language. Thus, the $\mathrm{L}_{2}$ writer has to become familiar not only with the linguistic forms of the language but also with the written discourse patterns and conventions of that language (See Reynolds, 2010; Robinson \& Ellis, 2011; Rosenberg, 2009; Sebba et al, 2011; Gossley \& Mc Namara, 2009; Revesz, 2009; Schoonen et al., 2009).

\subsection{Previous Research on Narrative Structure}

The features of $\mathrm{L}_{\mathrm{I}}$ and $\mathrm{L}_{2}$ narratives were compared in few studies. Harris (1983) asked his subjects to produce an account of a short cartoon film. He reported that the accounts written by $\mathrm{L}_{2}$ subjects had less to say on most of the narrative points, more often began in the middle of the story, less often referred explicitly to the film, and more often omitted essential scence setting elements than those of their NES counterparts. Indrasuta $(1987,1988)$ compared her native-Thai-speaking subjects' English narratives with those of their NES peers and with their $\mathrm{L}_{1}$ narratives. In the first comparison, she reported that the $\mathrm{L}_{2}$ subjects' texts exhibited more use of the first person singular, more backdrop setting (i.e., in which time and place are not important)- as opposed to the integral setting (i.e., in which characters, action, and theme are closely interwoven and thus setting is essential), less action, and more focus on mental states. In the second comparison, Indrasuta found more use the pronoun I, more implicit (as opposed to explicit) themes, more real (as opposed to projected) scenes, and less description of mental states in the $\mathrm{L}_{2}$ texts. Overall, she found that her $\mathrm{L}_{2}$ subjects' narrative patterns in English were closer to those in their $\mathrm{L}_{1}$ than they were to those used by NES subjects. Lin (1989) reported that the English narratives of her $\mathrm{L}_{2}$ writers (native speakers of Chinese) contained fewer complete episodes and fewer mentions of entities in episodes (the latter presumed to reflect a smaller lexical repertoire in English) than their Li versions (Silva, 1993:657).

One of the chief problems in setting common tasks for culturally and linguistically diverse groups is in finding common experience in the mode of writing selected, as well as knowledge of the subject matter to be written about. The rationale for choosing narrative tasks is as follows: (1) It is more likely that all of the students in the present study would have had experience with narration, whether in oral or written form; (2) Narrative compositions are the first type of composition that students learn in their native language (Indrasuta, 1988); (3) Narration is a socially evolved genre (Scribner, 1977); (4) Such genres as narration may vary from culture to culture and from speech community to speech community (Hymes, 1974); (5) Narration is also a familiar form and based on a simple type of organization.

Description and narration tasks have been found to be easier for native - speaker student writers to address successfully than other discourse modes, such as exposition or argumentation in elementary and secondary school as well as in the university. For example, Wilkinson et.al (1980) found that narrative and expository tasks "tap different types of linguistic, stylistic, cognitive, moral, and affective' considerations on the part of the writer" (P.90).

The fundamental importance of narration can be gathered from some of the epithets. used to describe it. Narrative is "a primary act of mind" (Hardy, 1987: I), "the primary scheme by means of which human existence is rendered meaningful" (Polkinghorne, 1988: II), "a means by which human beings represent and restructure the world" (Mitchell, 1981:8). It is "a specific cultural system" (Fawcett et al., 1984: 20), the "organizing principle ... by which "people organize their experience in, knowledge about, and transaction with the social world" (Bruner, 1990: 35). In this regard, Cortazzi (1993) maintains that when people tell stories, anecdotes and other kinds of narratives they are engaged in "a perceptual activity that organizes data into a special pattern which represents and explains experience" (Braningan, 1992: 3). Accordingly, Chafe (1990: 79) sees narratives as "manifestations of the mind in action: as windows to both the content of the mind and its ongoing operations". Therefore, narrative analysis can be seen as opening a window on the mind, or, if we are analyzing narratives of a specific group of tellers, as opening a window on their culture (Cortazzi, 1993: 2). (See Kormes, 2011; Ellis \&Yuan, 2004; Gilabert, 2005; Kang, 2005; Ishikawa, 2006).

Page | $161 \quad$ This paper is licensed under a Creative Commons Attribution 3.0 License.


Toolan (1998:137) points out that "narrative is distinguishable from description (a telling of the way things are). It is also distinguishable from much expository writing and expression of opinion, which are often explanations of the way things are, or an argument for the way you believe things should be. He, further, maintains that" a narrative is a text in which something humanly interesting has happened, or a significant change in the situation has occurred" (p.137). Also, in his book, Narrative: A critical linguistic introduction", Toolan (1988:136) defined narration as follows: "A narrative is at minimum a text (or text- like artistic production) in which the reader or addressee perceives a significant change. In a narrative, something happens, such that we sense a "before" and an "after": one state of affairs is displaced by a different state of affairs, and this latter state is, ideally, not merely temporally but causally related to the former state".

\section{Results}

As mentioned before, the subjects' written narrative texts were analyzed using Laböv' sociolinguistic model of narrative structure. Analyzing the narrative texts of both Arabic and Spanish students shows that their narrative essays have almost all the structural properties of Lobov's model (Abstract; Orientation; Complicating action; Evaluation; Resolution, and Coda) See Appendix 2).

The reader is reminded that, during the interview, each subject in both language groups was asked to describe how he/she approached the narrative text, how he/she started his/her essays, developed his/her thoughts and ended his/her essays. In addition, each subject was asked to describe how he/she would write the same narrative essay in his/her native language; whether it would be the same or different, and finally how each subject perceived his/her native language and culture as possible factors in shaping his/her written production. This means that, during the interview, each subject was asked to retrospect and reflect on the cognitive aspects of his/her writing processes of the text.

\subsection{Cognitive Aspects of Students' narrative Writing}

Based on the subjects' explanations, it can be argued that narrative writing was some kind of problem solving activity in which the subjects were faced with a difficult or problematic situation. What is at issue, here, is how the subjects approached the narrative assignment, and how they handled the problems that rose to the surface during the production of a narrative text.

First, the narrative assignment triggered various reactions; that is, students responded differently to the writing task. In fact, students' explanations show that their reactions were constrained by such factors as (1) their prior knowledge of what they were asked 'to write about, (2) their abilities to activate such knowledge, and (3) their own-perceptions of what stories should be. For example, Spanish subject (1) thought of a story that 'would be interesting; a story that would be a kind of unique, special, that wouldn't be boring, or wouldn't be that long and, something [she] could remember very well, that [she] could remember most of the details' (Line:925). Arabic subject (2) thought of 'something bad' that happened to him, as if writing a story is some kind of remembering sad events only; 'in the first stage I didn't think about something good that happened to me' (Line: 301 ).

Other subjects did not feel the need to spend much time in activating or searching for appropriate problems to write about. Rather, they thought only about the first situation they had encountered in the United States, and what it was all about. Arabic subject (3), for example, explained that he did not have to search for a problem to write about, and his first reaction or response to the writing task was thinking of the organization of his essay: how the problem (whatever it is) started, how it ended and how it was solved: 'I tried to organize my paper in these three aspects' (Line: 398). This does not mean that he did not have a specific problem in mind; rather, what this means is that subject (3) already knew what he would write about. Consequently, he did not feel the need to spend time searching for a problem. In other words, it appeared that the writing assignment gave subject (3) the cue to the topic of his essay. In this regard, he pointed out that he chose the transportation system in the U.S.A. to write about because it constituted the first serious problem that happened to him and, it was clear in his mind. That is why it was easy for him to start writing his story. He also indicated that he did not think of the details of his story:

S. 400 .

... I spent, maybe, two minutes just thinking about the structure of my writing, but when I was writing I did not think of organizing some ideas that will fill each paragraph because the story just came as a sequence.

What is most worth mentioning here is that some of the subjects did have a full and complete plan for their narrative writing including the details that their essays should include. However, the Arabic subjects (4) and (5) talked about having some overall general sense of direction, but not knowing in particular what they would say. Such behavior has been called in the literature 'what next strategy' (Bereiter \& Scardamalia, 1987). On the other hand, other subjects explained that they did not have any plans before starting to write. They were mainly 
interested in putting on paper what they remembered. The Spanish subject (3), for example, did not even think of organizing her thoughts; rather, she wrote what she remembered. And although memory activation played a vital role in the subjects' narrative writing, it caused some subjects to skip parts of words, articles and to forget to write down words they actually thought of. Also, as the Spanish subject (3) explained, she did not have to elaborate on anything because it was easy [for her] 'to remember what happened' (Line: 1204).

Spanish subject (1) pointed out that before she started to write the story, she did not have a specific plan for the structure of the story or how it would look. Rather, she started to recollect the events in terms of their order. And although Spanish subject (2) did not have a specific plan in his mind of how the story would look, he had an idea about some points to develop through the narrative essay: 'I never start writing without to have an idea in my mind of what points I want to write about' (Line:1086).

Spanish subject (3) indicated that she did not have any plan or schema in her mind of how the essay would look: 'I didn't know exactly what problem or experience I will be writing on' (Line: 1 194). And since she had to write something, she tried to remember everything related to her first arrival in the United States:

S.1196: I didn't have a specific problem... I just wrote my experience as it occurred at that time.

S. 1200: I just started and I followed what my memory reminds me of what happened... but I didn't know before I started that I will write these things.

Subject (3) indicated that it was easy for her to remember these events: 'because this happened to me and I have these things in my memory, and I will never forget them all my life' (Line: 1198). In addition, she pointed out that she was not concerned with the structure of her story in terms of beginning, middle and end. Rather, she wrote what she remembered: 'I didn't have to elaborate on anything because it was easy to remember what happened' (Line: 1204). Then, for subject (3), writing a narrative essay was just telling what happened as her memory operated during writing: 'I don't really know the rules... I just write'.

During the interview, the Arabic subject (4) indicated that when he read the writing assignment, he immediately thought of a problem he faced in the past, then, he started to recall the events, and, finally, thought of organizing these events and putting them in order. This sequence of actions implies that subject (4) did plan for his narrative essay." However, in terms of the content of his story, subject (4) indicated that he did not have a specific plan for what he would include in his story: he just started writing, relying on his memory:

S.532. $\quad . .$. sometimes, I write something before something else... that is why I have some kind of problems writing because, you know, sometimes I have to re-write some sentences because this happened before this or something like that.

Drawing on subject (4)'s verbal explanations during the interview, it is clear that his perception of the writing task determined, in part, the quantity of his written production in the narrative essay. For example, his story is remarkably the shortest one. When asked to explain why his story was short, he provided the following explanation:

S.550. Because I am trying just to be as much specific as you asked me to be, you know... I stick myself to your statement in the assignment... I put down what you were looking for.

Although Arabic subject (5) reacted to the first writing assignment as subjects (1), (2) and (4) did, he had his own perception of the writing task, which, consequently, determined the content of his story. That is, although he, first, thought of a problem or experience to write about, he, intentionally, wrote about an experience, not a problem:

S.687. I thought that writing about experience will be.. I can elaborate it more on writing or I can have more information about experience than if I concentrate on a single problem because the experience, I thought, it was more larger than a problem; so I can add or I can think about appropriate things about the experience.. I also wanted to write about something I will have no problem in going through the paper or in the chronicle order of the essay.

Subject (5) indicated that before starting to write the narrative essay, he had in mind a series of steps to follow': 'I have the major steps in my mind but the details I went through them during writing the story' (Line:699). Moreover, he wrote the story 'very quickly' because 'I remember all these... I went through this experience; I remember everything' (Line: 697). During the interview, the Spanish subject (5) pointed out that she did not plan for her writing; 'she just tried to express her ideas'. And she was not able to write correct sentences while 
attempting to put the ideas on the paper. She attributed this to two factors: (1) she was unable to think in English and (2) lack of practice. That is, although her academic study is in English, she rarely writes in English because her teachers of Latin American history gave her the permission to write in Spanish. Even if she had to write some papers in English, she tended to rely on her American friends who, at the same time, need her help in Spanish.

Moreover, students' explanations suggest that their main problems in writing narrative texts were (1) finding a topic to write about, and (2) starting their essays (opening statements), once topics were found. However, the subjects were able to overcome these two problems by adopting certain strategies. These were (1) a brainstorming process, (2) a memory search for a topic, which resulted in finding one complete problem to write about, pieces of problems, or one's overall experience in the United States, and (3) activation of prior knowledge that appeared pertinent to the writing assignment. Relatedly, students' behaviors during writing the narrative essay lend tentative support to the knowledge telling model (Bereiter \& Scardamalia, 1987). This model presents writing as a fairly natural task. And although the writing task may have its difficulties, writers can handle them by making maximum use of already existing knowledge structures. The composing process, according to this model, begins with a writing assignment. This model also allows for large differences in outcome depending on the writer's knowledge of the topic and on the writer's sophistication in the literary genre. Analyzing the subjects' explanations shows that their main difficulty during narrative writing was finding a problem to write about, and how to start their essays. Although this was not an easy problem for all subjects, they had ways to handle it and find solutions; either by a brainstorming process or memory search or by activating prior knowledge that appeared to be relevant to the topic. Having succeeded in finding a problem, the subjects appeared to have no problem writing the essay without even stopping to recollect or organize their thoughts. At this stage of the composing process, the subjects appeared to totally rely on their memory and their main task was just telling about the knowledge or the event of their stories.

Arabic subject (2) pointed out that 'it was difficult for him to choose a specific experience or problem to write about, because he had many ideas in his mind, but could not pick up one to be the topic of his story. His difficulty in choosing a problem was, also, due to the fact that he did not encounter 'strong or big bad experience... because I wasn't exposed to many problems'. Consequently, his narrative essay was not about only one problem; rather, 'it is more than one topic... more than one experience' (Line: 303). Moreover, he pointed out that his major problem in writing the narrative essay was how to start, not only the first paragraph, but also the first sentence of the essay: '....you know, when I finished the first sentence in the first paragraph I felt it is easier than the beginning' (Line: 31 1). When asked to explain why this was difficult for him, subject (2) gave the following explanation:

S. 313 When you start your essay or paper, you think about different problems... different ideas... so your mind is like bad radio... too many waves... too many stations at the same time.

Moreover, he indicated that it was difficult for him to think of ideas for his essay and write grammatically correct sentences. He provided the following explanation.

S.292. ... we think as foreigners... we think in our own language first and, then, transfer... translate it to English, but sometimes you have in your language but, sometimes, you have in your language but it is difficult to translate it... that what makes it difficult... and makes your grammar mistakes appear a lot.

Spanish subject (2), also, indicated that it was difficult for him to find a problem or experience to write about, but once he found it, it was easy for him to write down what he wanted. That is, he found it easy to move from one paragraph to another without stopping to recollect his thoughts:

S.1090 because the idea is one idea, but I developed in one paragraph to another, but if each paragraph has its own idea, this will be difficult ... but when I talked about the same idea, it is a lot easier.

His main problem however, was choosing the appropriate tense to express his ideas, 'that 1 was thinking and feeling something in the past but, at the same time, I have some reflections, ideas came at present' (Line:1092). He also indicated that it was easy for him to come up with ideas for his essay: however, it was difficult for him to express these ideas without making a lot of grammar errors. He also indicated that writing the narrative essay was not 'a big deal' because he had been studying and working at the University for a long time, which had resulted in a lot of reading and writing in English and, consequently, he had become familiar with writing as an activity. He also offered the following justification. 
S. 1098. my major of political science makes it easy for me to put things together... also, secondly; something personal or experience because you have that experience... you have to remember.

Spanish subject (3) indicated that her main problem in writing the narrative essay was how to start it. Moreover, she pointed out that her main problem in writing the narrative essay was keeping balance between her thoughts and the speed of her hand during writing.

The following is her explanation of this point:

S. 1210. may be my thoughts are faster than my writing... if I am not so fast, maybe I could pay attention to the organization... maybe, as we used to say, to put more flowers:.. to make the composition more nicely.

In contrast to subject (3), the Arabic subject (4) indicated that his main problem in writing the narrative essay was 'the opening statement'. In this regard, he gave the following explanation:

S. 536. how I will write it down... should I start this way, or this way or that way and how will I write it down... I know what happened in the first, but what I start with; that is my problem.

Having decided on his opening sentences, subject (4) pointed out that he had no problem developing his thoughts because 'it wasn't hard to recall' (Line: 538). At this point, he became concerned more with putting the events in order and in writing grammatically correct sentences:

S.538: here I know what I am going to write and then start thinking how I am going to write it down in good English... that is my problem.

Finally, the Arabic subject (5) indicated that he had no problem recalling all the events related to his story.

His main problem, however, was how to organize his story:

S.691. I had many things in my mind related to this experience; so where to start?... so, I

decided to write from I got the approval from the committee.

Spanish subject (1) indicated that she did not have any problem writing the narrative essay and, she explained the reason as follows:

S.933. Because... because I had very clear in my mind what was the story I want to write about.. I could recall it very easily... so, I didn't have any problem.

Furthermore, she pointed out that she thought of how she would start the story and, that is why she created, in her introductory sentence, what she called 'the context', 'where this story is occurred; when this .happened, and how this happened' (Line:933). However, when she was trying to recall the events of her story during writing, she had to skip parts of words, articles and, she was unable to write down words she actually thought of. As she explained, 'the process of thinking is much faster than the hand in writing' (Line: 935). It was however, easy for her to move from one idea to another because writing the story was a matter of just putting on paper what she recalled. That is, writing and recalling are one thing: 'it is not like you are recalling or writing two different events that are not related to one another' (Line: 939). Consequently, she did not stop writing until she finished her story. She then reviewed what she had written but did not change anything: 'I thought I said the story I wanted to tell' (Line: 941).

\subsection{Cultural Aspects of the Arabic Students' Narrative Writing}

Analyzing the Arabic subjects' explanations of their native culture's effect on their narrative writing indicated that most of the effect is attributable to the Arabic language. For example, Arabic subject (1) indicated that Arabic affected his choice of the topic he wrote about, the ideas he included in the essay and the style of his narrative essay. More interestingly, he pointed out that he was consciously aware of the interference of his native language, and allowed it to happen on purpose. Subject (2) also indicated that his native language added 'beauty' to his narrative essay. However, this made him use certain expressions that may sound good, but at the expense of the meaning of the whole structure. Arabic subject (3) pointed out that because of Islamic beliefs that call for mutual trust among people, he did not try hard enough to work on his ideas. In addition, he seemed to be angry at the educational system of his native country. Arabic subject (4) explained that he tended to repeat some structures or sentences as a habit inherited from his writing in the native language. He also admitted that although he had been in 
the U.S.A. for a long time, he could not help thinking and translating from his native language to English. Finally, Arabic subject (5) totally denied any effect of his culture on his narrative writing of the narrative essay.

The following is a discussion of the Arab students' explanations of how their culture affected their narrative writing.

\subsubsection{Choice of the Topic}

In their attempts to choose a topic for their narrative stories, some subjects appeared to resort to their native culture as a source of knowledge. It may be easy for them to write about something that is related to their life and traditions:

S.56. The greeting kiss itself is an Arabic theme... we Arabs are obliged to kiss each other when we greet each other and when I came here it was so odd to them... I was trying to kiss them and they were reluctant to do so.

\subsubsection{Rhetorical Style/Ideas}

The Arabic language, an inseparable component of the subjects' native culture, appeared to affect the ideas that the subjects used in their stories. As one of the subjects explained, Arabic is a metaphoric language, and he could not get rid of this aspect in. his writing in English: 'no matter how good it is some flavor of Arabic would be included in my English writing, especially metaphors and similes' (Line: 42):

S.42. ....my lips were so warm and desperate for a kiss on their cheeks.. their cheeks were blushing as if it were their first time.

S.44. in Arabic things that are dead but are not alive can be brought to life by a way of similes and metaphors and this, I think, is affecting my English writing.

In addition, some of the Arab subjects demonstrated sensitivity to cultural conventions, and used them strategically:

S.46 as long as the ideas are clear, the grammar is correct... the ideas will be conveyed safely to the nonnative speakers, even if this type of stylistics or similes is not in their own language.

When asked about the effect of his culture on his narrative essay, subject (2) pointed out that his Arabic culture added 'some beauty' to his writing of the narrative essay. However, from his verbal explanations, one can say that his culture affected his writing of the narrative essay negatively, because he tends to use words and expressions that may have a degree of beauty and eloquence in his native language, but do not fit the context in English. This observation appears to be compatible with the results of my study on thirty Arab students at Indiana University (El-daly, 1986). Specifically, it was found that. "In their written production, specialized students [in linguistics] tried to demonstrate their mastery of English by choosing expressions which may sound good enough, but they did not fit their contexts. In other words, they focused on the form at the expense of the pragmatic function of language" (p.51).

More interestingly, subject (2) indicated that adopting his native culture's threads of thinking is absolutely good. This explanation is based on his own belief that the Arabic or Islamic culture is very strong and, accordingly, he could not create his identity in a different culture, or change his own identity 'like the snake who changes its skin' (Line: 331 ).

Combining the results of El-daly (1986)'s study with those of the present study may show that the Arab students' written production, sometimes, is constrained by cultural factors in addition to students' linguistic competence in the target language (See Kimberly, 2009; Knutson, 2006; Lee, 2005; Renolds, 2010).

\subsubsection{Translation from $\mathrm{L}_{1}$}

Arabic subject (2) indicated that, during his writing of the narrative essay, he tended to think in his native language. Specifically, he felt that he was translating the events that involved his Arab friends and his wife:

$$
\begin{aligned}
& \text { S.319 everything happened to me almost in Arabic... so, it is hard to think in different } \\
& \text { language and then try to translate it to another language. }
\end{aligned}
$$

Furthermore, he pointed out the following: 'you try to structure sentences or paragraphs it is easier to structure it by your own language' (Line: 323 ).

Subject (4) indicated that although he had been in the United States for a long time, he still had to 'go through transition between thinking and how you will it in language, you know, because it is not your language' (Line: 540). More interestingly, subject (4) pointed out that although he tried to think in English during writing the

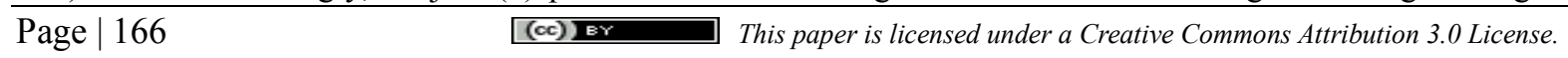


narrative essay, he could not help thinking in his native language: 'all your memory in a different language... you cannot change it' (Line: 542). Later on, subject (4) provided the following explanation:

S.544 you know, probably, I was thinking in Arabic in this way I write it down the way I am thinking in Arabic that is why it came differently.

In fact, subject (3) explicitly indicated that his native language affected his writing of the narrative essay, as follows:

S.408 I know the rules, the structures, grammar and the nature of writing in English but I cannot take myself out of the influence of my native language... that is my understanding... sometimes it is hard to write in English... sometimes I got lost.

When asked whether his native language affected his writing of the narrative essay, the Arabic subject (5) provided a rather interesting explanation. For him, the process of thinking whether in Arabic or English is something and the act of writing is something else. For him, consequently, although he was thinking in his native language, this did not affect, in any way, his written production, because he was writing in English, not Arabic:

S.701 ......................... I think in Arabic but there is no difference in thinking in Arabic and in English... but the next step is to write about these thoughts... the writing is in English... but there is, I think much influence about the thinking, but in writing it is all English.

Later on, subject (5) elaborated further on this issue when he denied the possibility of structuring his sentences, first, in Arabic and, second, translating them to English. He provided the following explanation:

S. 703. ... I didn't translate from language to language, but I think in my mind before I start any idea in Arabic... this is the thinking, but - when I start to write I write in English. I didn't try the sentence in Arabic and then translated to English. I used pure English.

Arabic subject (4) indicated that if he were to write the same narrative story in his native language, it would not significantly differ from the one he wrote in English. The only difference, however, would be that his story in Arabic would not have such a number of grammar errors. The following is his verbal explanation:

S.540. ... because I am going to recall and write the same while I am thinking it will not be any difficult for me because I know all the grammar of my native language and everything.

Subject (5) pointed out that if he were to write a similar story in his native language, it would differ from the one he wrote in English. Drawing on his verbal explanation, the differences would be linguistically - oriented. That is, because he is fluent in Arabic, his story in Arabic would be clean from grammar errors:

S.707 ...... I am fluent in Arabic; this means that I can write very good sentences without any mistakes... because in English, as I said, I have some problems in the tenses, some parts of the English language, but in Arabic I have no such problems because when I write in Arabic it is easy.

In terms of organization and the overall structure of the story, subject (5), also, pointed out that his story in Arabic and English will be different. Drawing on his verbal explanations during the interview, one can argue that this difference is mainly due to the level of competence in both languages, which is, naturally, higher in Arabic than it is in English:

S.71. In Arabic, if I want to write a story about experience, I control the language; so I can put an introduction better than the one I put here in the English essay; I can use many phrases better than the ones I used in this essay. I mean give them a very nice look for the reader, because many words I can remember in Arabic, but not the same as in English...

\subsubsection{Arabic Educational Systems and Insufficient Writing Instruction}

Arabic subject (3) pointed out that his native culture affected his writing in English in two ways: (1) because all Arab students have one type of audience who share their ideas, thoughts and Islamic beliefs, they tend not to work hard 'to support their ideas'. (2) Arab students did not learn to write in Arabic and/or English: 'I don't believe that Arabs try to write in a certain way... we are taught nothing' (Line: 416 ):

S.450. I believe that Arabs are not trained to write either in Arabic or English. 
International Journal of Applied Linguistics \& English Literature

ISSN 2200-3592 (Print), ISSN 2200-3452 (Online)

Vol. 1 No. 6; November 2012

S.454. If you are trained in good writing style, you will be able to organize your writing in English and if you are trained to write a good writing in Arabic, then, you will be able to take your writing seriously in English.

S.456. in writing we don't think of organizing our papers... just write something... I mean in home we say this is writing... that is not important... as a result we are not good either in Arabic or English.

From the above explanations, one can perceive that subject (3) was furious and angry at the educational systems in Arab states:

S.416 although I know the structure and style of writing in English, but since I have not been trained to do so, I have difficult time to write in English... if I have been trained I could be writing a lot better.

\subsubsection{Repetition}

Arabic subject (4) indicated that the only way in which his native culture affected his writing of the narrative story was that he, as all Arabs, repeated some statements more than once. What he meant by this is represented in the sentence 'I asked him how much I am going to pay him'. In fact, the repetition of 'him' is mainly due to interference from Arabic grammar.
Arabic
Ana sa?ltuhu kam sa? dfaluhu
English
I asked-him how much will pay-him?

'I asked him how much I am going to pay him'.

Consequently, it seems that the cultural effect is represented only in his native language's influence on his writing. In this regard, subject (4) gave the following explanation:

S.554. ... culture affects the language, you know, but the culture itself, I could adjust myself to the culture, you know, I have been here for almost four years... then, I know how the people think, how the people talks, how the people put their, even, ideas on the paper, but not as perfect as them.

\section{Cultural Aspects of the Spanish Students' Narrative Writing}

Based on the subjects' explanations, it seems that there is no consensus among the Spanish subjects regarding the effect of the Latin American culture on their narrative writing. Although, Spanish subject (1) indicated that both Spanish and American cultures are similar, subject (2) indicated that they are different. Their different perceptions controlled their beliefs about their own cultures as a factor of shaping their narrative written productions. Spanish subject (1) indicated that her native culture affected her choice of the topic, which represents the emotional side of her character. Also, her native language interfered in forming many of her English grammar structures. Subject (2) indicated that his native language did not affect his narrative writing because he wrote about something personal, and relied on what he remembered. However, Spanish grammar interfered in structuring many of his English sentences in the narrative essay.

In addition, subject (3) denied totally any effect of her native culture on her writing, whereas subject (4) indicated that her culture affected her choice of the story she wrote about, without feeling any shame of writing about something that may seem stupid. However, she did her best not to sound as a Spanish speaker. That is, she tried not to reveal her identity through writing.

The following is a discussion of the Spanish subjects' explanations of how their native culture affected their narrative writing.

\subsection{Divided Opinion about the Effect of Culture on Writing}

Spanish subject (1) pointed out that Spanish culture does not significantly differ from the American culture and, accordingly, Spanish culture does not affect her writing of the narrative essay:

S. 946. Spanish culture and American culture are different, but these differences are not huge differences... I mean, you will still be speaking about the western mentality... western ideology... Spanish culture is part of the European model. ... almost everything in Spanish and English and any Romance language is the same.

Regarding Latin American culture's effect on his writing of the narrative essay, Spanish subject (2) indicated that 'the person is conditioned by the question and the topic' and his choice of the problem he wrote about was 
International Journal of Applied Linguistics \& English Literature

ISSN 2200-3592 (Print), ISSN 2200-3452 (Online)

Vol. 1 No. 6; November 2012

influenced by his culture, which differs from the American culture (See Van Weijen et al., 2008; Weijen et al., 2009).

\subsection{Choice of the Topic}

Subject (I) did not deny the fact that being a Latin American, she sees things more emotionally and, as she pointed out, this is part of her culture. And, that is why she chose this particular story to write about: 'this story means a lot of value to me' (Line: 951):

S.953. The whole story has a lot of meaning to me because it was nice... it was nice to find a woman who was willing to help a stranger, that is the normal in my country.

S.957 the story means a lot to me because of my background... I give big value to it because of my culture... so, the story is of great value because of my own values and culture.

As Spanish subject (4) explained, the Spanish people are not ashamed to express what they feel, whereas Americans are not willing to talk about something 'in which they will look stupid to the reader' (Line:1270). Subject (4), further, added the following: We don't care... we like to have fun... I mean, we tell what happened to us, and that is it. When asked if she can cite an example from her story to illustrate the influence of her culture on her writing, she referred to the incident in which her Latin American group reacted 'stupidly' to earthquakes: 'I guess that is part of my culture... Japanese may react the same way as we did; Americans wouldn't' (Line: 1272).

\section{$6.3 L_{1}$ Interface}

Subject (1) indicated that her native language affected the way she structured the sentences but, it did not affect the ideas or the overall organization of her story:

S.943 but I did recall the story in English, because I was writing in English.

Later on, subject (1) explained her rationale as follows:

S.947. if you are thinking in Spanish, you say it perfectly well in Spanish... if you are thinking in English, you say it in English... the meaning gets through, but you don't pay much attention to grammar... because what is important is the meaning... if you get through with the meaning, this means that you are, at least the way I feel it, I'm thinking in English and I'm saying this in English.

Subject (1) indicated that if she were to write the same story in her native language, there would not be any difference between her story in English and the one in Spanish:

S.943 in writing this story I just sat down and I remembered and I wrote what I remembered... in Spanish if I want to write something like this... I will sit and write what I remembered... the same way I did in English.

Although subject (2) admitted that Spanish sometimes interfered in his writing of the narrative essay, he indicated that Spanish did not have such a big effect on him 'because this is personal and writing about experience... you write what you remember' (Line:1102). Therefore, as he explained, he did not 'make mechanical translation from Spanish sentences to English but... there is some reflections from Spanish grammar. Sometimes, aspects of Spanish grammar interfered' (Line: 1104). Subject (2) indicated that if he were to write such a story in Spanish, there would not be a big difference between his essay in Spanish and the one he wrote in English. The only difference, according to subject (2), would be that his story in Spanish would not contain as many errors as the one in English. Spanish subject (3) indicated that if she were to write such a story in Spanish, she would use the English style; not the Spanish one. She demonstrated understanding of the differences between both styles: 'in Spanish we use long sentences... we use more long sentences and not more specific... but when I write in English I don't do that; I try to be more specific' (Line:1212). With this in mind, she added that when she writes to a Spanish friend or someone who speaks Spanish, she uses the same structure... short sentences... short paragraphs'. Consequently, she felt that if she were to write the narrative essay in Spanish, her essay would not differ from the one she wrote in English. When asked to explain how she can follow the English style of writing although her native language is Spanish, she could not explain the factors that helped her to accomplish this: 'I don't really know... I just notice that, maybe because I write a lot in English and I read a lot too... I don't know how I reached this'.

Spanish subject (5) indicated that if she were to write a similar story in Spanish, she would be able to elaborate more on her ideas and the essay would be more political: 'Because I have other feelings in respect to the United States I cannot express in the English.' 


\subsection{Identity}

Subject (4) indicated that she is always aware that her native language, sometimes, interferes in her writing in English, but she tries to avoid it as much as possible. To accomplish this, she tended to think in English: 'and whenever I noticed that my sentence was basically a reflection of Spanish, I changed my sentence. I am always aware when I am writing' (Line: 1276). More important is the reason that subject (4) tried not to sound as a Spanish speaker:

S.1278 Spanish speakers have the most Hispanic stigma in this culture. But it depends on from where you came. You from Spain, you, then, have the highest status... if you come from Argentina, you have the second rank, if you came from central America, you will have the lowest status... so being Hispanic is not something good... so, I tried not to show that I was Hispanic in my writing.

This means that some of the Spanish subjects tried not to reveal their cultural identity in writing. The Arabic subjects, however, did not have any problem revealing their identities. This does not mean that the Arabic subjects are more proud of their culture than the Spanish subjects; rather, it may be due to the fact that all the Arabic subjects were males, and the Spanish subjects, except subject (2), were females. This may be a gender characteristic more than it is a cultural one.

\section{Conclusion}

The results of this study seem to support Perl (1980a, 1980b) findings regarding the behavior of students writers. Specifically, Pert found that both skilled and unskilled writers discover their ideas in the process of composing. Composing, as described by some of the subjects, seems to be a process of discovery, exploring ideas and presenting them in the best way possible. It is creative and may not be based on a clear sense of direction or explicit plan. It is true that some of the subjects indicated that they had a specific plan before writing their essays; however, their plans were not static but rather dynamic, that is, it allows for further discovery and exploration. In other words, the subjects of this study seemed to experience writing as a process of creating meaning. Rather than knowing from the outset what is it they will say, these students explore their ideas and thoughts on paper, discovering in the act of doing so not only what these ideas and thoughts are, but also the form with which best to express them.

Moreover, the composing behaviors of both Arabic and Spanish speakers appeared to correspond to what the knowledge-telling model says. Based on the subjects' explanations, it is clear that writing narrative texts was a matter of just telling about the knowledge or the events of their stories and letters. Relatedly, their main concern in writing the narrative essay was to find a problem, and once this problem was found, all subjects explained that they did not have any problem putting ideas on paper. However, there was no interaction between text processing and knowledge processing, as the knowledge transforming model maintains. That is, neither students' writing nor their knowledge had been developed as a result of a lack of interaction between the process of writing and students' existent knowledge. According to Bereiter and Scardamalia (1987), knowledge-transforming strategies are only found in people who actively rework their thoughts, consider whether the text they have written says what they want it to say and whether they themselves believe what the text says. In the process, they are likely to consider not only changes in the text but also changes in what they want to say. Thus, it is that writing can play a role in the development of their knowledge. In addition, the composing behaviors of the subjects do not totally support Flower and Hayes' (1980) model of writing. Specifically, in terms of planning not all subjects planned for their writings. Those who planned for their writings were of two types: (1) some of the subjects did have a full and complete plan for their writing, including the details that their essays should include, (2) other subjects did have a general sense of direction, without knowing in particular what they would say. Bereiter and Scardamalia (1987) called such behavior "what next strategy." Some other subjects explained, however, that they did not have any images, proposition or feelings of knowledge to be used in writing. Rather, they wrote what they remembered; one event after the other. The Spanish subject (3), for example, did not think of organizing her thoughts and, as she said, she did not have to elaborate on anything because it was easy for her "to remember what happened."

In addition, the only mental process that was identified by Flower and Hayes, and also found in the subjects' behavior was the process of "translating," which is defined as the process of turning ideas into written language. However, the two mental processes "reviewing" and "monitoring," as defined by Flower and Hayes, were never reported by the subjects except the Arabic subject (1) and the Spanish subject (4).

Analyzing the Arabic subjects' explanations of their native culture's effect on their narrative writing indicated that most of the effect is attributable to the Arabic language. For example, one of the Arabic subjects indicated that 
Arabic affected his choice of the topic he wrote about, the ideas he included in the essay and the style of his narrative essay. More interestingly, he pointed out that he was consciously aware of the interference of his native language, and allowed it to happen on purpose. Another subject also indicated that his native language added 'beauty' to his narrative essay. However, this made him use certain expressions that may sound good, but at the expense of the meaning of the whole structure.

Arabic subject (3) pointed out that because of Islamic beliefs that call for mutual trust among people, he did not try hard enough to work on his ideas. In addition, he seemed to be angry at the educational system of his native country. Arabic subject (4) explained that he tended to repeat some structures or sentences as a habit inherited from his writing in the native language. He also admitted that although he had been in the U.S.A. for a long time, he could not help thinking and translating from his native language to English. Finally, Arabic subject (5) totally denied any effect of his culture on his narrative writing of the narrative essay.

In addition, based on the subjects' explanations, it seems that there is no common theme among the Spanish subjects regarding the effect of the Latin American culture on their narrative writing. Although, Spanish subject (1) indicated that both Spanish and American cultures are similar, subject (2) indicated that they are different. Their different perceptions controlled their beliefs about their own cultures as a factor of shaping their narrative written productions. Spanish subject (1) indicated that her native culture affected her choice of the topic, which represents the emotional side of her character. Also, her native language interfered in forming many of her English grammar structures. Subject (2) indicated that his native language did not affect his narrative writing because he wrote about something personal, and relied on what he remembered. However, Spanish grammar interfered in structuring many of his English sentences in the narrative essay. Moreover, subject (3) denied totally any effect of her native culture on her writing, whereas subject (4) indicated that her culture affected her choice of the story she wrote about, without feeling any shame of writing about something that may seem stupid. However, she did her best not to sound like a Spanish speaker. That is, she tried not to reveal her identity through writing.

Moreover, based on the Spanish subjects' explanations, it seems that the Spanish culture's effect was constrained by such factors as (1) the subjects' perceptions of their own culture, and the target culture, as well. It seems that the Spanish subjects tended to intentionally disreveal their identities as Hispanic. This attitude took various forms, either suggesting that their persuasive writing is a combination of Spanish and American cultures; denying the effect of their native culture altogether; claiming that this is the way they write without knowing whether Spanish affected their written productions or not, or indicating that they followed the American style of writing. This is not to suggest that the Spanish subjects were not proud of being Hispanic. Quite the contrary, they demonstrated a great loyalty to their own native culture. But, they seemed to be concerned about other people's opinions of them and their culture. So, to play it safe, they tended to disreveal their identity.

In conclusion, this study suggests that writing in a second language involves three interrelated skills: linguistic, cognitive, and cultural. Regardless of language proficiency, students also need to master the essentially non-linguistic intellectual and cognitive skills which underlie writing. This suggestion goes hand in hand with what Crystal (1998:5) calls for:

"Language has no independent existence living in some sort of mystical space apart from the people who speak it. Language exists only in the brains and mouths and ears and hands and eyes of its users. When they succeed, on the international stage, their language succeeds. When they fail their language fails" (p.5)

A word of caution is due: the findings of the present study are limited only to this sample, instrument, and the conditions under which the research was done. The subjects may not be representative of all Arabic and Spanish speakers, and ESL learners. Besides, gender characteristics (male vs. female) could be an intervening factor in students' performance. Therefore, further research is needed to replicate the results of this study.

\section{References}

Alwi, N., Adams, R. \& Newton, J. (2012). Writing to learn via text chat: Task implementation and focus on form. Journal of Second Language Writing 21:23-39.

Beare, S. and Bourdages, J. (2007). Skilled writers' generating strategies in $\mathrm{L}_{\mathrm{I}}$ and $\mathrm{L}_{2}$ : An exploratory study. In $\mathrm{G}$. Rijlaarsdam (Series Ed.) \& M. Torrance, L. Van Waves \& D. Galbraith (Vol. Eds.). Studies in Writing, vol. (20), Writing and Cognition Research and Applications (pp. 151-161). Amsterdam: Elsevier.

Bereiter, C. and Scardamalia, M. (1987). The psychology of written composition. Hillsdale, NJ: Lawrence Erlbaum Associates. 
International Journal of Applied Linguistics \& English Literature

ISSN 2200-3592 (Print), ISSN 2200-3452 (Online)

Vol. 1 No. 6; November 2012

Bickner, R. and P. Payasantiwong. (1988). Cultural Variation in Reflective Writing. In A. Purves(ed.) Writing. Across Languages and Cultures. London and Newbury Park, CA: Sage.

Bitchener, J. \& Bastukman, H. (2006). Perception of the difficulties of post graduate $\mathrm{L}_{2}$ thesis students writing the discussion section. Journal of English for Academic Purposes, 1-15.

Bloom, A. (1981). The Linguistic shaping of Thought : A Study in the Impact of Language on Thinking in China and the west. Hillsdale, NJ: Erlboun.

Boas, F. (1986/1911). Linguistics and Ethnology. In F. Boas(ed.), Handbook of American Indian Languages. Washington, D.C.: Smithsonian Institute.

Branigan, E. (1992). Narrative Comprehension and Film . London, Routledge.

Brown, R. (2009). Students' and teachers' perception of effective foreign language teaching: A comparison of ideals. The Modem Language Journal 93: 46-60.

Bruner, J. (1990) . Acts of Meaning. Cambridge, MA, Harvard University Press.

Carter, R. (1997). Investigating English Discourse - Language, Literacy V and Literature. London and New York.

Casanave, C. P. (2004). Controversies in second language writing: Dilemmas and decisions in research and instruction. Ann Arbor: The University of Michigan Press.

Chafe, W. (1990). Some Things That Narratives Tell us about the Mind. In B. Britton, and A. Pellegrini (eds.), Narrative Thought and Narrative Language. Hillsdale, N J, Lawrence Erlbaum.

Chandler, D. (2011). Semiotics: The Basics. Routledge, Taylor \& Francis Group.

Cobley, P. (2011). The Routledge Companion to Semiotics. Routledge, Taylor \& Francis Group.

Conley, M. (2008). Cognitive strategy instruction for adolescents: at we know about the promise, what we don't about the potential. Harvard Education Review, 78 (1), 84-106.

Connor, U. and Mc Cagg, P. (1983). Cross- Cultural Differences and Perceived Quality in Written Paraphrases of English Expository prose. Applied Linguistics, 4, 259-268.

Connor, U. (1987). Research frontiers in writing Analysis.

Cortazzi, M. 1993. Narrative Analysis. The Falmer Press.

TESOL Quarterly 21,677-96.

Crossley, S.A. \& McNamara, D.S. (2009). Computational assessment of lexical differences in $\mathrm{L}_{1}$ and $\mathrm{L}_{2}$ writing. Journal of Second Language Writing 18: 119-135.

Crystal, D. (1998). English as a Global Language. Cambridge University Press.

Cumming, A. (1987). Decision Making and Text Representation in ESL writing Performance. Paper Presented at the 21 st Annual TESOL Convention, Miami.

Darvishzadeh, P., Aguilar-Vafaie, M. \& Ali, M. (2012). A comparative study of working memory executive functions processing efficiency considering high and low levels of anxiety. Journal of Second Language Writing 32: 40-44.

Doolan, S. \& Miller, D. (2012). Generation 1.5 written error patterns: A comparative study. Journal of Second Language Writing 21:1-22.

El-dali, H. (2010). Second language learners' metalinguistic ability and classroom instruction: $1 \mathrm{~J}$ Focus on grammaticality judgements. Journal of Language and Literature (56): 46-62.

El-daly, H. (1986). An analytical study of lie syntactic errors of Arab students in the skill of writing in English. Master Thesis, Bloomington, IN.

Ellis, R. \& Yuan, F. (2004). The effects of planning on fluency, complexity and accuracy in second language narrative writing. Studies in Second Language Acquisition 26: 59-84.

Eslamim, Z. and Fatahi, A. (2008). Teachers' sense of self efficacy, English proficiency, and instructional strategies. A study of nonnative EFL teachers in Iran. TESL-EJ, 11 (4).

Fawcett, R., M. Halliday, S. Lamb, and A. Makkai. (1984). The Semiotics of Culture and Language. vol. (2). London, Pinter.

Ferris, D. \& Hedgcock, J. 2005. Teaching ESL composition: Purpose, process, and practice. $2^{\text {nd }}$ ed., Mahwah, NJ: Lawrence Erlbaum.

Field, J. (2011). Psycholinguistics. Routledge, Taylor \& Francis Group.

Freidlander, A. (1990). Composing in English: Effects of a First Language on written in English as a second Language. In B. Kroll(ed.) Second Language Writing. Cambridge, England and New York: Cambridge University Press.

Galloway, V. (1985). Communicating in a Cultural Context. Wakfield, / MA.

Galloway, V. (1992). Toward a Cultural Reading of Authentic Texts. In H. Byrnes (ed.), languages for a Multicultural world in Transition. National Textbook Company. 
International Journal of Applied Linguistics \& English Literature

ISSN 2200-3592 (Print), ISSN 2200-3452 (Online)

Vol. 1 No. 6; November 2012

Gardner, R. and W. Lambert. (1972). Attitudes and Motivation in Second Language Learning. Rowley, Mass: Newbury House.

Gass, S. (1983). The development of $\mathrm{L}_{2}$ intuitions. TESOL Quarterly, vo. 17 (2): 273-291.

Gilabert, R. (2005). Task complexity and $\mathrm{L}_{2}$ narrative oral production. Unpublished doctoral thesis. University of Barcelona.

Grabe, W. and R. Kaplan. (1989). Writing in a Second language: contrastive Rhetoric. In D. Johnson and D. Roes (eds.) Richness in writing. London and New York: Langman. 263-83.

Gregorious, C. (2011). Language, ideology and identity in serial killer narrative. Routledge, Taylor \& Francis Group.

Hansen - Strain (1992). Orality/ Literacy and Group Differences in Second Language Acquisition. Language, 3i: 205-212.

Hardy, B. (1987). The Collected Essays of Barbara Hardy, vol. (1). Sussex, Harvester Press.

Harris, M. (1983). Cultural anthropology. New York: Harper \& Row.

Hedgcock, J. (2005). Taking stock of research and pedagogy in $\mathrm{L}_{2}$ writing. In Handbook of Research in Second Language Teaching and Learning, ed. E. Hinkel, 597-613. Malwah, New Jersey: Lawrence Erlbaum.

Hinds, J. (1983). Contrastive Rhetoric : English and Japanese. Text 3, 183-95.

Hirose, K. (2003). Comparing $\mathrm{L}_{1}$ and $\mathrm{L}_{2}$ organizational patterns in the argumentative writing of Japanese EFL students. Journal of Second Language Writing 12 (2), 181-209.

Hoffman, C., Ivy, L. and D. Johnson. (1986). The Linguistic Relativity of Person Cognition: An English-Chinese Comparison. Journal of Personality and Social Psychology 51 (6).

Hua, Z. (2011). The language and intercultural communication reader. Routledge, Taylor \& Francis Group.

Hull, G. (1989). Research on writing: Building a Cognitive and Social Understanding of composing. In R., Resnick, and L.klopfer.(eds.) Toward the Thinking Curriculum:. Current Cognitive Research. Alexandria, VA.

Hymes, D. (1974). Foundations of Sociolinguistics: An Ethnogrophic Approach. Philadelphia: University of Pennsylvania Press.

Indrasuta, C. (1987). A Comparison of the written Compositions of American and Thai students. Dissertation Abstracts International 48(7).

Indrasutra, C. (1988). Narrative styles in the Writing of Thai and American students. In A. Purves (ed.) Writing Across Languages and Cultures. Newbury Park, CA: Sage. 206-26.

Ishikawa, T. (2006). The effect of manipulating task complexity along the [+/- Here-and-Now] dimension on $\mathrm{L}_{2}$ written narrative discourse. In C.M. Garcia-Mayo (Ed.), Investigating tasks in formal language learning (pp. 136-156). Clevedon, UK: Multilingual Matters.

Jiang, N. (2007). Selective integration of linguistic knowledge in adult second language learning. Language Learning-57 (1): 1-33.

Jones, S. and J. Tetroe. (1987). Composing in a Second Language. In A. Matsulrashi(ed.) writing in Real Time. Norwood, NJ: Ablex.

Kachru, Y. (1989). Cross-Cultural Texts, Discourse Strategies and discourse Interpretation. In Smith (ed), Discourse Across Cultures: Strategies in World Englishes. Englewood Cliffs, NJ: Prentice Hall.

Kang, Y.J. (2005). Written narratives as an index of $\mathrm{L}_{2}$ competence in Korean EFL learners. Journal of Second Language Writing 14: 259-279.

Kaplan, R. (1972). The Anatomy of Rhetoric: Prolegomend to a Functional Theory of Rhetoric. Philadelphia: Center for Curriculum Development.

Kaplan, R. (1988). Contrastive Rhetoric and Second Language learning: Notes Toward a Theory of Contrasive Rhetoric. In A. Purves (ed) Writing Across Languages and Cultures. London and Newbury Park, CA: Sage. 275-304.

Kaplan, R. (1966). Cultural Thought Patterns in Intercultural Education. Language learning 16, 1-20.

Kellogg, R. (1996). A model of working memory in writing. In C.M. Levy \& S. Ransdell (Eds.), The Science of Writing: Theories, Methods, Individual Differences and Applications (pp. 57-71). Mahwah, NJ: Lawrence Erlbaum.

Kimberly, A. (2009). Adult learners' perceptions of the incorporation of their $\mathrm{Li}$ in foreign language teaching and learning. Oxford University Press.

Klimova, B. (2011). Evaluating writing in English as a second language. Journal of Second Language Writing 28:390-394.

Knutson, E. (2006). Thinking in English, writing in French. The French Review 80 (1): 88-109. 
International Journal of Applied Linguistics \& English Literature

ISSN 2200-3592 (Print), ISSN 2200-3452 (Online)

Vol. 1 No. 6; November 2012

Kormos, J. (2011). Task complexity and linguistic and discourse features of narrative writing performance. Journal of Second Language Writing 20:148-161.

Kuiken, F. \& Vedder, I. (2008). Cognitive task complexity and written output in Italian and French as a foreign language. Journal of Second Language Writing 17: 48-60.

Laböv, W. (1972). The Transformation of Experience in Narrative Syntax. In "Language in the Inner City", University of Pennsylvania press.

Lee, S. (2005). Facilitating and inhibiting factors in English as a foreign language writing performance: A model testing with structural equation Modeling. Language Learning 55 (2), 335-374.

Leeuwen, T. (2011). Introducing social semiotics. Routledge, Taylor \& Francis Group.

Leki, I. (1991). Twenty-Five Years of Contrastive Rhetoric: TEXT Analysis and Writing Pedagogies. TESOL Quarterly 25,123-43.

Leki, I., Cumming, A. \& Silva, T. (2008). A synthesis of research on second language writing. London: Routledge.

Lin, C. (1989). The structures of English and Chinese Narratives, written by College graduates in Taiwan. Dissertation Abstracts International 50 (7).

Loewen, S., Li, S. and Thompson, A. (2009). Second language learners' beliefs about grammar instruction and error correction. The Modern Language Journal 93: 91-104.

Manchón, R.M, Roca de Larios, J. \& Murphy, L. (2009). The temporal dimension and problem-solving nature of foreign language composing processes: Implications of theory. In R.M. Manchón (ed.), Writing in Foreign Language Contexts: Learning, Teaching and Research. (pp. 102-129). Bristol: Multilingual Matters.

Mangubhai, F. (2006). What do we know out learning and teaching second languages: Implications for teaching: Asian EEL Journal 8 (3): 1-20.

Marshal, S. (1979). Cognition: Information Processing in Various Cultures. In S. Marshall (ed.), Cross-Cultural Psychology; Human Behaviour in Global. Perspective. Monterey, CA: Brooks/Cole.

McCarthey, S.J., Guo, Y.-H. \& Cummins, S. (2005). Understanding changes in elementary Mandarin students' $\mathrm{L}_{1}$ and $\mathrm{L}_{2}$ writing. Journal of Second Language Writing 14 (2): 71-104.

McCutchen, D. (1996). A capacity theory of writing: Working memory in composition. Educational Psychology Review 8: 299-325.

Mitchell, W. (1981). On Narrative. Chicago, IL, Chicago University Press.

Mu, C. \& Carrington, S. (2007). An investigation of three Chinese students' English writing strategies. TESL-EJ 11(1): 1-22.

Nation, I. (2009). Teaching ESL/EFL Reading and Writing. New York: Routledge.

Onaka, N. 1984. Developing Paragraph Organization skills at the College level, English Teaching Forum, 14-22.

Ong, J. \& Zhang, L.J. (2010). Effects of task complexity on the fluency and lexical complexity in EFL students' argumentative writing. Journal of Second Language Writing 19: 219-233.

Ostler, J. (1988). Seeing with different eyes: Another view of literature in the ESL class. TESOL Quarterly, 23(3), 557-584.

Perl, S. (1980). The Composing Processes of Unskilled College writers. Research in the Teaching of English 13,317-36.

Petric, B. (2012). Legitimate textual borrowing: Direct quotation in $\mathrm{L}_{2}$ student writing. Journal of Second Language Writing 21:102-117.

Polkinghome, D. (1988). Narrative, Knowing and the Human Sciences. Albany, NY.

Purves, A. (1988). Writing Across Languages and Cultures. New bury Pork, CA: Sage.

Radford, A. (1981). Transformational Syntax. A student's Guide Chomsky's Extended Standard Theory. Cambridge Textbooks in Linguistics.

Regent, O. (1985). A Comparative Approach to the learning of Specialized written Discourse. In Riley, P. (ed.), Discourse and Learning. London: Longman.

Reid, J. (1990). Responding to Different Topic types: A Quantitative Analysis from a Contrastive Rhetoric Perspective. In B. Kroll (Ed.), Second Language writing: Research Insights for the classroom.. New York: Cambridge University Press.

Révész, R. (2009). Task complexity, focus on form, and second language development. Studies in Second Language Acquisition 31: 437-470.

Reynolds, D. (2010). Assessing Writing, Assessing Learning. Ann Arbor., MI: University of Michigan Press. 
Robinson, P. and Ellis, N. (2011). Handbook of cognitive linguistics and second language acquisition. Rout ledge, Taylor \& Francis Group.

Rosenberg, R. (2009). Tools for activating materials and tasks in English language classrooms. English Forum 47 (4): 2-11.

Rumelhart, D. (1975). Notes on a Schema for Stories. In D., Bobrow and A. Collins (eds. Representation and Understanding : Studies in Cognitive Science, New York: Academic Press.

Sapir, E. (1949/1921). Language: An Introduction to the study of speech. New York: Harcourt Brace Jovanevich. Sapir, E. (1964/1931). Conceptual Categories in Primitive Languages. In D. Hymes (ed.) Language in Culture and Society: A Reader in Linguistics and Anthropology. New York: Harper and Row.

Schoonen, R., Gelderen, A., Glopper, K., Hultijn, J., Simis, A., Snellings, P. \& Stevenson, M. (2003). First language and second language writing: The role of linguistic knowledge, speed of processing, and metacognitive knowledge. Language Learning 53 (1): 165-202.

Schoonen, R., Snellings, P., Stevenson, M. \& van Gelderen, A. (2009). Towards a blue print of the foreign language writer: The linguistic and cognitive demands of foreign language writing. In R.M. Manchón (Ed.), Writing in Foreign Language Contexts. Learning, Teaching and Research. (pp. 77-101). Bristol: Multilingual Matters.

Scribner, S. (1977). Modes of thinking and way of speaking: Culture and lagic reconsidered. In Laird - Johnson, P. and Mason, P. (eds.), Thinking: readings in cognitive science. Cambridge University Press.

Sebba, M. \& Mahootian, S. and Johnson, C. (2011). Language mixing and code-switching in writing. Rout ledge, Taylor \& Francis Group.

Segalowitz, N. (2011). Cognitive bases of second language fluency. Routledge, Taylor \& Francis Group.

Shehadeh, A. (2011). Effects and student perceptions of collaborative writing in $\mathrm{L}_{2}$. Journal of Second Language Writing 20:286-305.

Silva, T. (1993). Toward an Understanding of the Distinct Nature of $\mathrm{L}_{2}$ Writing: The ESL Research and its Implications. TESOL Quarterly 27: 657-77.

Simon, P. (1980). The Tongue-Tied American. New York: Continuum.

Soler, A. (1988). The second language learner and cultural transfer in narration. In A. Purves (ed.) Writing across languages and cultures. London and New bury Park, CA: Sage. $177-205$.

Spada, N. (2006). Communicative language teaching: Current status and future prospects. In J. Cummins \& C. Davis (eds.), The International Handbook of English Language Teaching. Norwell, MA: Springer.

Stigler J. and Hiebert, J. (2009). The teaching gap: Best ideas from the world's teachers for improving education in the classroom. Free Press.

Toolan, M. (1998). Language in Literature: An Introduction to Stylistics. Arrowsmith, Bristol, Great Britain. Tyler, A. (2011). Applying Cognitive Linguistics. Routledge, Taylor \& Francis Group.

Vahapassi, A. (1988). The Problem of Selection of Writing Tasks in Gross-Cultural study. In A. Purves (ed.) Writing Across Languages and Cultures. London and Newbury Park: CA: Sage. 51-78.

Valdes, J. (1989). Cultural Bound. Bridging the Cultural Gap in Language Teaching. Cambridge University press. Van Patten, B. and Williams, J. (2008). Theories in Second Language Acquisition. New York: Routledge.

Van Weijen, D., Van den Bergh, H. Rijlaarsdam and Sanders, T. (2008). Differences in process and process product relations in $\mathrm{L}_{2}$ writing ITL. International Journal of Applied Linguistics 156, 203-226.

Walker, J. (2011). Variation in linguistic systems. Routledge, Taylor \& Francis Group.

Weijen, D., Bergh, H. and Rijlaarsdam, G and Sanders, T. (2009). $\mathrm{L}_{1}$ use during $\mathrm{L}_{2}$ writing: an empirical study of a complex phenomenon. Journal of Second Language Writin 18, 235-250.

Whorf, B. (1956). Language, Mind, and Reality, in J. Carroll (ed.), Language, Thought, and Reality: Selected writings of B. Lee. Whorf. Cambridge, Mass, MIT Press.

Wilkinson, A.; Barnsley, G.; Hanna, P., and Swan, M. (1980). Assessing Language Development. Oxford : Oxford University Press.

Wong, A.T.Y. (2005). Writers' mental representations of the. intended audience and of the rhetorical purpose for writing and the strategies that they employed when they composed. System 33, 29-47.

Wong, L. (2001). Switching to first language among writers with differing second language proficiency. Journal of Second Language Writing 12: 347-375. 


\section{WRITING TASK ONE: NARRATIVE ESSAY}

Think back to when you arrived in the United States for the first time. Write a story about a problem or experience you had. Be sure to clearly describe this problem where it happened, who was involved, how you felt at that time, and how you reacted.

\section{LABÖV' SOCIOLINGUISTIC MODEL}

\section{APPENDIX TWO}

1. Abstract. This is a short summary of the story that narrators generally provide before the narrative commences. It "encopsulates the point of the story". The question which- this property seems designed to answer is "what, in a nutshell, happened?"

2. Orientation is an essential constituent in helping the reader to identify in some way the time, place, persons, and their activity or situation". It can include " an elaborate portrait of the main character". Orientation can be marked by "many past progressive verbs, and, obviously, adverbial phrases of time/ manner and place". The question which this property seems designed to answer is "who was involved? When and where was this?

3. Complicating action: contains narrative clauses. Such clauses have a verb which is simple past or simple present. They are the minimal units of the narrative and are temporally ordered, in that "a change in their order will result in a change in the temporal sequence of the original semantic organization". For example, "The girl got pregnant. The girl married" is a very different story if the clauses are reversed. The question which this property seemed designed to answer is "what happened first? Then what happened?

4. Evaluation: Like the basic narrative clause, this is the most important element in narration. Evaluation can take many shapes and be marked by a number of different linguistic forms:

\section{A. Evaluation: Commentary}

1. External: Comments by the narrator external to the action and addressed directly to the interlocutor.

2. Internal: comment is embedded:

a) The evaluative comment occurs to the narrator or character at a specific moment of the action;

b) Comment is addressed to another character;

c) Evaluative remarks are attributed to a third party.

\section{B. Sentence - Internal Evaluation Devices}

1. Intensifiers: e.g. gestures, expressive phonology, repetition, interjection.

2. Comparators: generally speaking, a "comparator moves away from the line of narrative events to consider unrealised possibilities and compare them with events that did not occur"

The question which the Evaluation property seemed designed to answer is "How have you added to the basic story, to highlight how it is interesting or relevant to your addressee or to you, the teller?

Resolution: this contains the last of the narrative or free clauses which begin the complicating action. The question which this property seemed designed to answer is "what finally happened?". Not all naratives, however, have a clear resolution: it is quite possible for a narrative to report a "problem" without providing a solution.

Coda: the coda should provide a sense of completeness, signalling that the story has ended and has been evaluated by bringing "the narrator and the reader. back to the point at which they entered the narrative". This property answers the question, "How does the story relate to us, here and now?. or it supplies a moral lesson learned by the protagonist or teller.

In his discussion of Laböv's six elements of narrative texts, Toolan (1998) maintains that "at the heart of a typical narrative.. two somewhat contrasting demands need to be met: one is the structural demand for a sequentially related set of events expressing a change from one state to a different one, and the other is the functional demand that this reported change of state and its implications should be interesting, instructive, entertaining, or worth the telling. The structural demand is met by the complicating action and resolution material... while the functional demand is met by the evaluative material" (p.138). 